\title{
譯文项資粕
}

\section{皮膜構成用尿素一フォルムアルデヒド 縮合物の構造と性質との研究}

T. S. Hodgins and A. G. Hovey

Ind. Eng. Chem., 1938, 30, 1021

旸生龍郎譯

Ellis 氏 ${ }^{(24)}$ の尿素-フォルムアルデヒド反應化學に關する調査を觀るとJohn 氏 ${ }^{(32)}$ の研究以前既に此方面 に相當多数の研究者が居つた事が解る。John 氏の呼究發表直後は尿素ーフォルムアルデヒド縮合物を型造用結

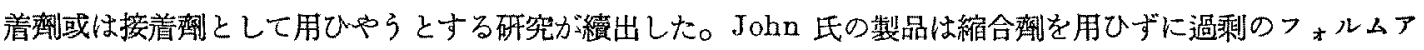
ルデヒト（特に縮合劑を使用せずとすフォルムアルデヒド中には蜬酸が含有されてをり之れが縮合劑 (42)とし ての效果を現はすものと現今に於ては一般に認められてをる）を使用し縮合して得たもので、是は接着齊、型 造用結清劑及び織布用熱硬化性含浸劑として使用し得ると言ふ事である。

Kamstetter 氏 ${ }^{(38)}$ 及び Crump 氏 ${ }^{(18)}$ は樹脂狀縮合物を朌水する目的で反應混合物に有機溶劑を加へた。 皮膜形成用としての尿素樹脂の發達は Lanter 氏 (33) の發見に始まり同氏はグリセりン又は其他の多價アルコ ールの或一定量の存在で尿素とフォルムアルデヒドとを反應せしむる時は生成する樹脂はアルコール、其他の 非水性溶劑に溶解する事を發見したのである。有機溶劑の存在に低る水性縮合物の脫水法としては其外に Riprer ${ }^{(41)}$,Luther, Pungs, Griessbach, Heuck 氏 ${ }^{(35)}$ 等の研究がある。

Hill 及び Walker 氏 ${ }^{(29)}$ は油紧形アルキッド樹脂及び一價アルュールと尿素-フォルムアルデヒト中間物と の縮合に就いて報告した。又筆者等 (31 は尿素-フォルムアルデヒド及び多監基性酸一多價アルコール（後者過 剩使用) 中間反應物の一價アルコール中に於ける共同繀合物 (Co-Condensation)に就いて報告した。

Cheethom 及び Pearce 氏 ${ }^{(16)}$ は染料用としての尿素ーフォルムアルデヒド反應生成物に就いて發表して居 る。

一般反應

水溶媒中に於ける反應：水溶媒中に於ける尿素一フォムアルデヒドとの反應の一般理論に關しては多くの研 究者の見解は大體に於て一致して居る。一般に縮合生成物は (a) 使用觸媒の與入る反應溶液の $\mathrm{pH}$ ，(b) 反應 成分の分子比並に(c) 反應時間及び溫度等に依つて影響せられるものである。

尿素 モルとフォルムアルデヒド 1 モルとは水酸イホンの存在に於てはモノィチロールニレアを生成す $3^{(23)}$ 。 


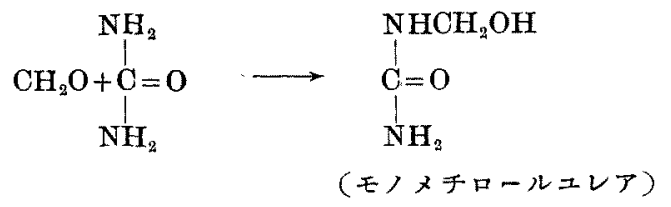

フォルムルデレドが過剩なる時（尿素１モル、フォルムアルデヒド2モル）はヂィチロールュレアを生ず $ろ^{(23)}$ 。

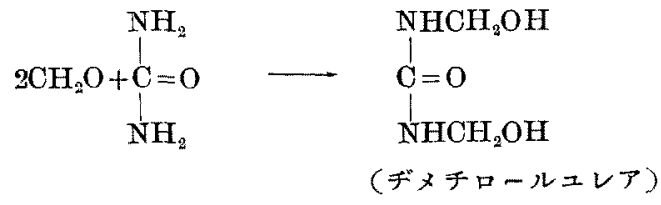

稀溥酸の存在に於ては不溶性の白色無定形メチレンユレアを形成する(34)。<smiles>COC(N)(N)OCCO</smiles>

又 Hälzer(30)氏に依れば

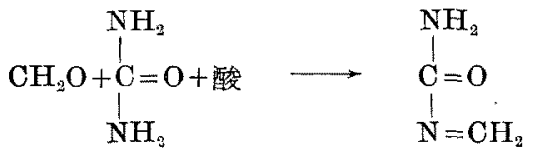

水溶媒中に於ける反應機構：此反應機構に就ては各樣の說あるも就中 Goldschmidt(26), Dixon (21), Staudinger (46), Scheibler ${ }^{(43)}$, Walter ${ }^{(47,48)}$, Chesne ${ }^{(17)}$ 氐等の研究が有名である。尿素 1 モルとフォルムアルデ ヒド 2 モとの反應により最終生成物に到る過程には二つの機椣郎ち (a) デメチロールュレア中間物を經て縮 合する機構と (b) ヂィチレンエレアを經て重合する機構とがある樣に考へられる。

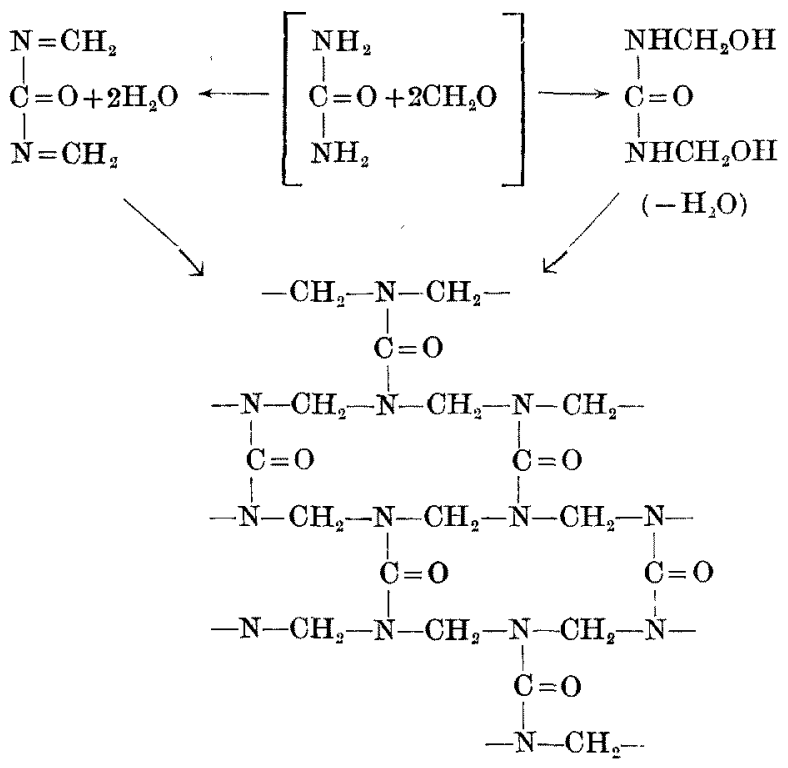




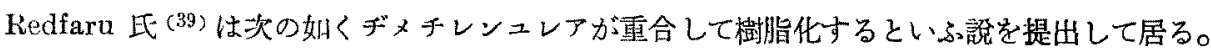<smiles>CCN(C)C(=O)N1CCN(C(=O)N2CCC2)C1=O</smiles>

此構造は㨁鎖狀のポリマーで、樹脂化理論に從へば熱非硬化性樹脂と考へられる型である。尿素ーフォルムア ルデヒド重合體は長く加熱すれば容易に不可逆性のがルとなつて三次元棈造に變移する事實から考察する時は 此楧选式は全然當を得て居らないもの之言はざるを得ない。

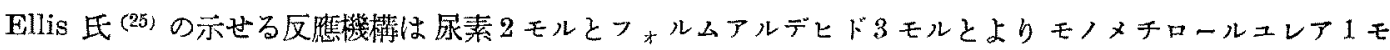
ルとヂメチロールニレア1モルとを生成し、次に更に此等が結合してメチロールカルバミルー4ーケトーキサヒ ドロトリアデンを生成すると云るのである。<smiles></smiles>

此のわの こルが縮合すると

$$
\text { } \mathrm{CO} \cdot \mathrm{NH} \cdot \mathrm{CH}_{2}-\mathrm{N}_{\mathrm{CH}^{2}-\mathrm{N}}^{\mathrm{CO}-\mathrm{NH}} \overbrace{\mathrm{CO} \cdot \mathrm{NH} \cdot \mathrm{CH}_{2} \mathrm{OH}}^{\mathrm{CH}_{2}-\mathrm{N}}
$$

となり、其單位ポリマーは次の樣に示される。

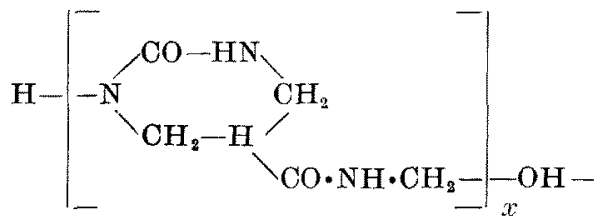

分子比を斯樣（尿素2モル、フォルムアルデレド3モル從つてヂメチロールニレア1モル、モ)メチロール エレア 1 モルを生ず）に選撢すればメチロールカルバミルー4ーケトーキサヒドロトリアヂンを形成する可能性 はあるが然し Redfaru 氏の說明に對すると同一理由（直鎖狀ポリマーは熱非硬化性）で 7 式及び 8 式に示さ れて居る構造は、ゲル化するに必要なる交夏結合 (Cross linkage) を行ふ餘地なき篇めポリマー單位として は不满足でする。筆者は實驗的に尿素樹脂はゲル化する事を確めた、並置せる直銭狀ポリマー間のある位。置に て更に分子が反應して交叉結合を起す事を登明しなければゲル化現像の證明にはならない。

縮合中問生成分子か總てデォチロールニレア（尿素1モルに對しフォルムアルデヒド2モルの場合）とすれ ば、モノー放びデメチロールュレア等分子混合物（Ellis 氏の述べし如く尿素2モルに對しフォルムアルデヒド 3 モルの場合)の時よりも三次元的空間に反應する機會多く從つて 4 式に示せる構造を形成するに最も有利で ある筈である。モノメチロールニレアは 4 個の反應性因子 (3つの活性水素原子と 1 つの活性水酸基) を持つ て居るから假今ヂィチロールュレア分子を生成せずしてモノメチロールニレア分子のみを生成するとしても直 
鑚狀構造間に交文結合を起し仍て熱硬化性に變移する可能性がある。普通にはモノメチロールニレアと其に若 干のヂメチロールエレアる坐成するから複雜な檴造を形成する機會が一層多くなり從つて熱硬化性の樎合物を 生ずる事になるのである。

一價及び多價アルコールと尿素ーフォルムアルデとドとの縮合

一價及び多價アルコールよりアセタールの生成 : 尿素樹脂をペイント及びワニス工業に倠用するには其等は 普通の淦材用溶劑、樹脂、ラッカ一等と良く混合するものでなくてはならない。办中で縮合せしめた樹脂はの イント及びワニス用材料と相溶しない。然し乍ら或種の一價アルコール或は多價アルコール又は此等混合液の 存在にて尿素ーフォルムアルデヒドを縮合せしめると炭化水素溶渓に可溶性の樹脂が得られる。尿素樹脂の性質 は反應溶媒の種類例へば承或はアルコールに依つて影響せられるから篻者等は其の何れの場合に於ても溶媒は 樹脂生成に或役割をなすものと考へて居る。郎ちフォルムアルデヒドは一價又び多價アルコール又は混合アル コールと篮基性反應によりアセタールを形成し、次に之れが尿素と縮合して單位ポリマーを生ずるものである と信じて居るのである。

一價アルコールとしては反應性大にして且つ水を恒沸點混合液を作るブチルアルュールを使用して賔驗を行 つた。

複合多價アルコール：使用したる多價アルコールはエチレングリコールとグリセりンとで、且つ無水フター ル酸 1 モルとエチレングリコール2モルとよりの反應生成物をも使用した。後者の反應物の構造式は理諭的に は次の樣に示されてる。<smiles>O=C(OCCO)C1CCCC2C(=O)OCCOCC12</smiles><smiles>CC(O)C(CO)OC1C(=O)OC2CCCCC21</smiles><smiles>O=C1OCCCCC1C(=O)OCC(O)C(O)COC(=O)C1CCCCC1C(=O)OCC(O)CO</smiles><smiles>CCOC(=O)C1CCCCC1C(=O)OCC(O)C(O)O</smiles> 
賔際には斯樣な化合物が單獨に分離せらるものではないが、複合二價アルコールの形を有する事は明かであ る。同樣に無水フターール酸 3 モル、ダリセロール4モルよりは連鑟の長さを巽にする複合多價アルコール型の 反應物を生ずる、其の反應は次の如く書き表す事が出來る。

向此場合無水フタール酸に 對してグリセロールの分子比が濄剩なる 等と且つ反應溫度が 比較的に低い事

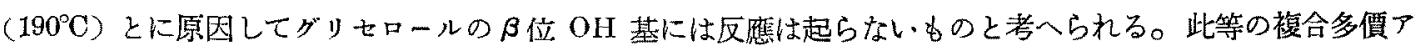
ルコール（反應式 9 及 10) の生成に當り反應を同一點にて中止せしもべき目安としては酸價を測定する。

一價及び多價アルュールは共にアルデヒドと容易にアセタール(第1表)を形成する故に前記の如き複合多 便アルュール型の反應生成物む办椱合アセタールを生し、之れが次に簡單なるア゙タールの場合に於けると同 樣に尿素と反應することは容易に首肯し得られる。

尿素ーフォルムアルデヒド縮合物生成に於ける變形劑としての是等複合多價アルュールの工業的用途に關して は本報交の後章に堾て述べる事とする。

正ーブチルフォルマールの生成: 尿素とフォルムアルデヒドとの縮合をブチルアルコールの如き一價アルュー ルの存在に於て行ふ时は水溶媒の場合と異り最䘞にアルコールとアルデとドとの反應が行はれる。

$$
\begin{aligned}
& \mathrm{CH}_{2} \mathrm{O}+2 \mathrm{HOCH}_{2} \cdot \mathrm{CH}_{2} \cdot \mathrm{CH}_{3} \longrightarrow \\
& \mathrm{CH}_{2}\left(\mathrm{O} \cdot \mathrm{CH}_{2} \cdot \mathrm{CH}_{2} \cdot \mathrm{CH}_{2} \cdot \mathrm{CH}_{3}\right)_{2}+\mathrm{H}_{2} \mathrm{O} \\
& \text { (IEブチルフォルマール) }
\end{aligned}
$$

正ーブチルフォルマールはブチルアルコールの過剩の場合に生成するが、アルコールが一定限度郎ちアルデヒ ード1モルに對してアルコール1モルの㭙にはへミアセタールを生成する傾问がある。

$$
\begin{aligned}
& \mathrm{CH}_{2} \mathrm{O}+\mathrm{HOCH}_{2} \cdot \mathrm{CH}_{2} \cdot \mathrm{CH}_{2} \cdot \mathrm{CH}_{3} \rightarrow \mathrm{CH}_{\mathrm{O}}^{\mathrm{OH}} \cdot \mathrm{CH}_{2} \cdot \mathrm{CH}_{2} \cdot \mathrm{CH}_{2} \cdot \mathrm{CH}_{3} \\
& \text { (正ブチルへミフォルマール) }
\end{aligned}
$$

アセタールの性質 : 第 1 表に比較的重要なるアゼタールを揭示して置いた。此等は尿素と反應して鉒膜材料 と相溶性のある樹脂を作るものである。ア七タールの一般生成反隹式を示せば

\begin{tabular}{|c|c|c|c|c|c|}
\hline 蹹 & $\begin{array}{l}\text { 式督造 式 } \\
\text { フオルムアルデヒードより }\end{array}$ & M. P. $\left({ }^{\circ} \mathrm{C}\right)$ & B. P. $\left({ }^{\circ} \mathrm{C}\right)$ & Sp. Gr & 交 \\
\hline $\mathrm{C}_{5} \mathrm{H}_{12} \mathrm{O}_{2}$ & $\mathrm{CH}_{2}\left(\mathrm{OC}_{2} \mathrm{H}_{6}\right)_{2}$ & - & $87 \sim 88$ & $0.8 \backsim 1\left(0^{\circ} \mathrm{C}\right)$ & $(3,15)$ \\
\hline $\mathrm{C}_{7} \mathrm{H}_{12} \mathrm{O}_{2}$ & $\mathrm{CH}_{2}\left(\mathrm{O} \cdot \mathrm{CH}_{2} \cdot \mathrm{CH}: \mathrm{CH}_{2}\right)_{2}$ & - & $138 \sim 139$ & 0.8948 & 3) \\
\hline $\mathrm{C}_{9} \mathrm{H}_{16} \mathrm{O}_{2}$ & $\mathrm{CH}_{2}\left(\mathrm{O} \cdot \mathrm{CH}_{2} \cdot \mathrm{CH}_{2} \cdot \mathrm{CH}: \mathrm{CH}_{2}\right)_{2}$ & - & $175 \sim 177$ & - & (3) \\
\hline $\mathrm{C}_{9} \mathrm{H}_{20} \mathrm{O}_{2}$ & $\mathrm{CH}_{2}\left(\mathrm{O} \cdot \mathrm{CH}_{2} \cdot \mathrm{CH}_{2} \cdot \mathrm{CH}_{2} \cdot \mathrm{CH}_{3}\right)_{2}$ & --61.5 & $180 \sim 181$ & - & $(3,9,2$ \\
\hline $\mathrm{C}_{8} \mathrm{H}_{20} \mathrm{O}_{2}$ & $\mathrm{CH}_{2}\left[\mathrm{O} \cdot \mathrm{CH}_{2} \cdot \mathrm{CH}\left(\mathrm{CH}_{3}\right)_{2}\right)_{2}$ & - & 164.3 & $0.825\left(20^{\circ} \mathrm{C}\right)$ & $(1$, \\
\hline $\mathrm{C}_{11} \mathrm{H}_{24} \mathrm{O}_{2}$ & $\mathrm{CH}_{2}\left[\mathrm{O} \cdot \mathrm{CH}_{2} \cdot \mathrm{CH}_{2} \mathrm{CH}\left(\mathrm{CH}_{3}\right)_{2}\right\rfloor_{3}$ & - & 207.3 & $0.835\left(20^{\circ} \mathrm{C}\right)$ & $(2$, \\
\hline $\mathrm{C}_{11} \mathrm{H}_{24} \mathrm{O}_{2}$ & $\mathrm{CH}_{2}\left[\mathrm{OCH}_{2} \mathrm{CH}\left(\mathrm{CH}_{3}\right) \mathrm{CH}_{2} \mathrm{CH}_{3}\right]_{2}$ & - & 205 & - & 3 \\
\hline
\end{tabular}

$$
\begin{array}{ll}
\text { アャタール } & \mathrm{RCHO}+2 \mathrm{R}_{1} \mathrm{OH} \rightarrow \mathrm{RCH}\left(\mathrm{OR}_{1}\right)_{2}+\mathrm{H}_{2} \mathrm{O} \\
\text { ヘミアセタール } & \mathrm{RCHO}+\mathrm{R}_{1} \mathrm{OH} \rightarrow \mathrm{RCH}
\end{array}
$$

第 1 表 $ア セ$ \ 


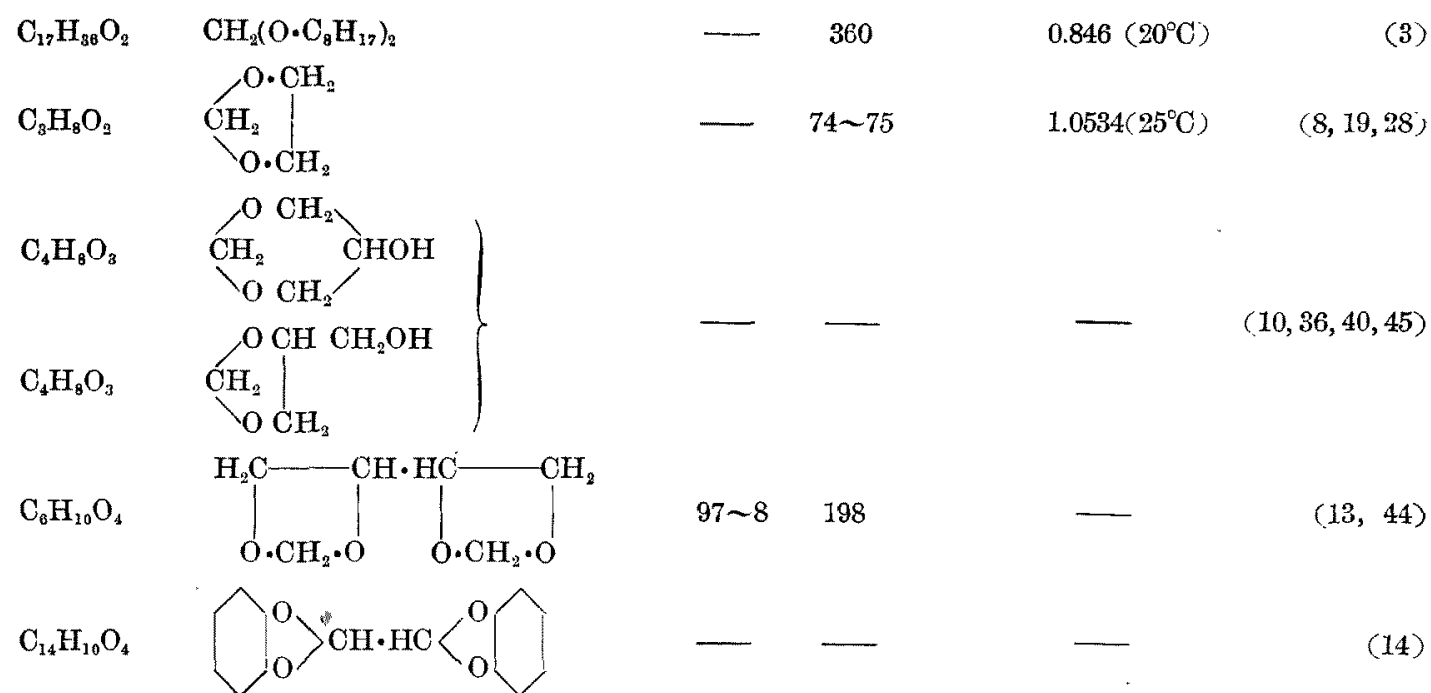

$$
\text { アセトアルデヒード及び高級アルデヒードより }
$$

$\mathrm{C}_{4} \mathrm{H}_{10} \mathrm{O}_{3} \quad \mathrm{CH}_{3} \cdot \mathrm{CH}\left(\mathrm{OCH}_{3}\right)_{2}$

$\mathrm{C}_{4} \mathrm{H}_{10} \mathrm{O}_{2} \quad \mathrm{CH}_{3} \cdot \mathrm{CO}(\mathrm{OH}) \cdot \mathrm{OC}_{2} \mathrm{H}_{5} \quad-\quad 80 \sim 90 \quad-$

$\begin{array}{lllll}\mathrm{C}_{6} \mathrm{H}_{14} \mathrm{O}_{2} & \mathrm{CH}_{3} \cdot \mathrm{CH}\left(\mathrm{O} \cdot \mathrm{C}_{2} \mathrm{H}_{5}\right)_{2} & - & 102.2 & 0.821\left(22^{\circ} \mathrm{C}\right) \\ \mathrm{C}_{8} \mathrm{H}_{18} \mathrm{O} & \mathrm{CH} \cdot \mathrm{CH}\left(\mathrm{O} \cdot \mathrm{C}_{3} \mathrm{H}_{7}\right)_{2} & - & 146.8 & 0.825\left(22^{\circ} \mathrm{C}\right)\end{array}$

$\mathrm{C}_{10} \mathrm{H}_{22} \mathrm{O}_{2}$

$\mathrm{CH}_{3} \cdot \mathrm{CH}\left(\mathrm{O} \cdot \mathrm{C}_{3} \mathrm{H}_{7}\right)_{2}$

$168 \sim 170$

$0.816\left(22^{\circ} \mathrm{C}\right)$

$\mathrm{C}_{14} \mathrm{H}_{26} \mathrm{O}_{2} \quad \mathrm{CH}_{3} \cdot \mathrm{CH}\left[\mathrm{O} \cdot \mathrm{CH}_{2} \cdot \mathrm{CH}\left(\mathrm{CH}_{3}\right) \cdot\right.$

207 209

$0.8255\left(21^{\circ} \mathrm{C}\right)$

$\mathrm{C}_{12} \mathrm{H}_{23} \mathrm{O}_{2}$

$\mathrm{CH}_{3} \cdot \mathrm{CH}\left[\mathrm{O} \cdot \mathrm{CH}_{2} \cdot \mathrm{CH}_{2} \cdot \mathrm{CH}\left(\mathrm{CH}_{3}\right)_{2}\right]$

210.8

$0.8347\left(15^{\circ} \mathrm{C}\right)$

$\mathrm{O}_{6} \mathrm{H}_{8} \mathrm{O}_{2}$<smiles>CC1OCCO1</smiles>

82.5

$1.0002\left(0^{\circ} \mathrm{C}\right)$

$(8,49)$

$\mathrm{C}_{5} \mathrm{H}_{10} \mathrm{O}_{3}$<smiles>CC(OCC(O)CO)OCC1OC(C)OC1C</smiles>

$\mathrm{O}_{5} \mathrm{H}_{10} \mathrm{O}_{3}$ $\mathrm{O} \cdot \mathrm{CHC}_{2}$ 
原素とアセタッルとの反應：尿索がアセタールと反應して縮合單位を生成する理䄖的反應式は次の通りです る。

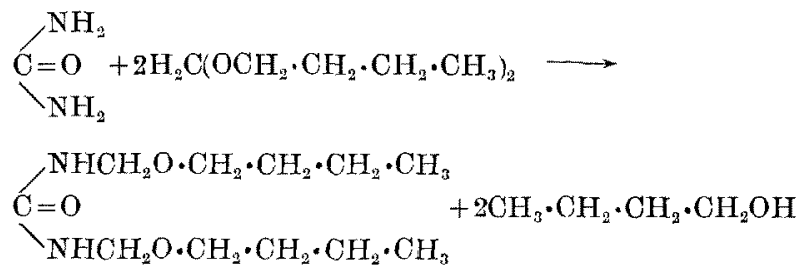

是等の哩位は水溶媒中に於ける機構々同樣（反應 4 式參照）更に縮合作用を次の如く進行寸る。

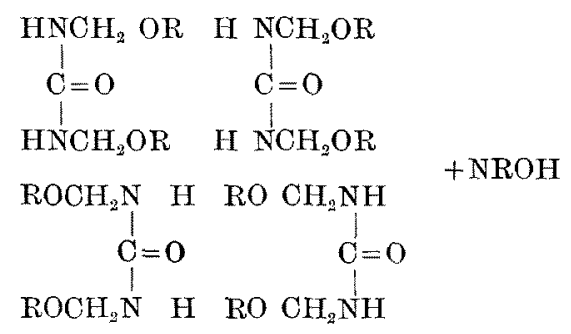

水及びアルュール溶媒中に於ける反應物：尿素 1 モル（60g)、37\%フォルマリン2モル（162g)を密閉器中 にて反應せしめると樹脂液 $222 \mathrm{~g}$ 中に樹脂分 $84 \mathrm{~g}$ 師 $37.9 \%$ を得る。之れは尿素 1 モル當、り樹脂 $84 \mathrm{~g}$ にし て1:1.40の比になる。之れより觀察すれば反應は次の如く進行寸るものと思考せられる。

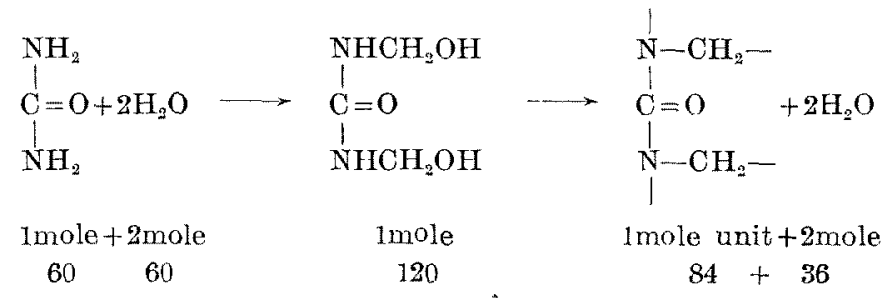

此の構造嘿位は理論上次の組成を持つ、

$$
\begin{aligned}
2 \mathrm{~N} & =38=33.3 \% \\
3 \mathrm{C} & =36=42.8^{\prime \prime} \\
\mathrm{D} & =16=19.1^{\prime \prime} \\
4 \mathrm{H} & =\frac{4}{84}=\frac{4.8^{\prime \prime}}{100.0}
\end{aligned}
$$

水の存在にて得たる尿素ーフォルムアルデド縮合生成物の實测㱖素含有量（N=35.2\%）は理論值より稍了 多い。Dixon 氏 (21) は空素含有量 $32.8 \%$ を報告して居るが之れは理論值と良く一致する。

窒素含有量の理諭値と賽測値とを比較すると其等は比較的近似して居り又更に理論量の樹脂が得られた事䆩 から考察すると單位ボリマーの構造は反應式 17 にて表はし得れるものと思ふので岁る。

次に尿素1モル $(60 \mathrm{~g})>_{\star}$ ルムアルデヒド3モル（水液 $243 \mathrm{~g} ）$ とブチルアルニール1モル（74g）中に て縮合せしめると樹脂 $158 \mathrm{~g}$ を得る。

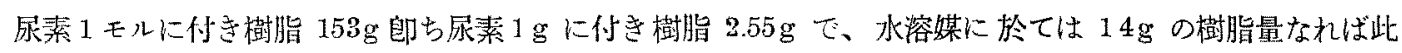
事からブチルアルュールは尿素とフォルムアルデヒドとの反踓に與る事を知るのである。 


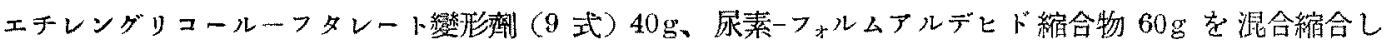

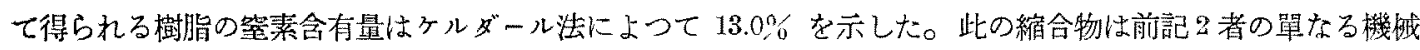

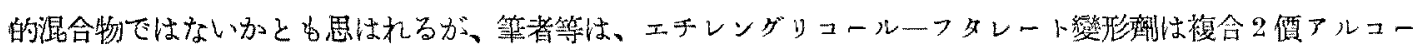
ルの如く作用し之れが前記ブチルアルコールと同樣に尿素ーフォルムアルデとドと作用するるのと信ずるのであ る。

グリコールーフタレート變形齊の模造は椱雜で、これが尿素ーフォルムアルデヒドとの縮合生成物は更に錯雜

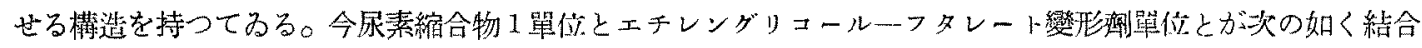
するとすれば<smiles>CCOC(=O)C1CCCCC1C(=O)OCCOCCN(C)C(=O)[Al]C</smiles>

其の生成物單位中には更に反應に與るべき多くの位置を殘留して居る事になる。此の假定單位中の等素含有 歶は理諭上 $8.47 \%$ であるが（算測值 $13.0 \%$ ) 尿素ーフォルムアルデヒドのポリマー單位はエチレングリコール

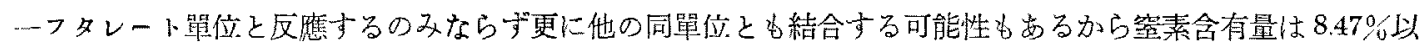
上に昇ることもあらろと思はれる。尿素ーフォルムアルデヒドのポりマー置位中の理論上の䇪素含有量は $3930 \%$ である

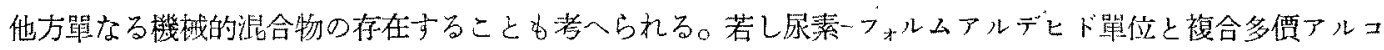
一ル單位とが 18 式に示与反應より更に進行して、一價アルコールの場合（16式）の樣になるとすれば多價ア

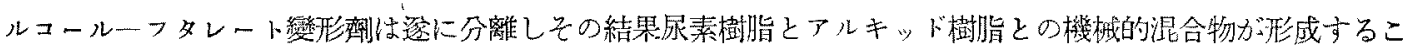
とになる。

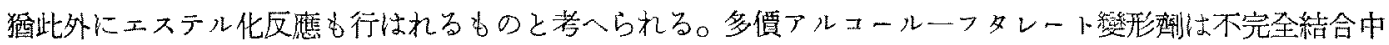

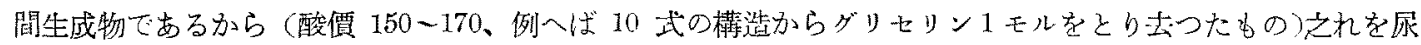

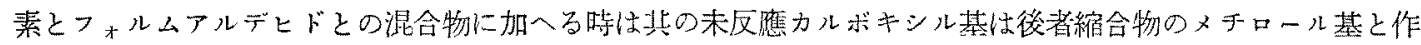
用してェステル結合を行ふのである。

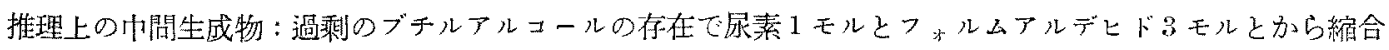

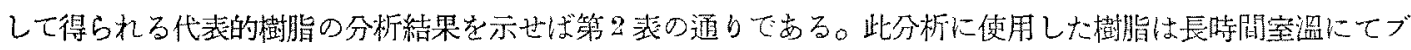

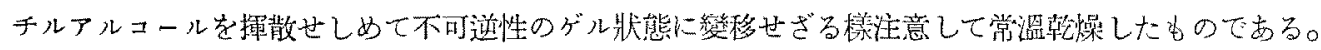

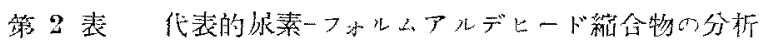

\begin{tabular}{|c|c|c|c|c|}
\hline & & 5 口 & 10 日 & 本 约 \\
\hline 萑 & 素 & $49.90 \%$ & $50.06 \%$ & $49.98 \%$ \\
\hline 然 & 素 & 18.57 & 18.46 & 18.52 \\
\hline 水 & 素 & 8.43 & 8.84 & 8.63 \\
\hline 酸 & 素 (养) & 23.10 & 22.10 & 22.89 \\
\hline
\end{tabular}

此表によれば、邅剩のブチルアルコールの存在に於ける尿素とフォルムアルデヒドとの反應物は雨者の初期 
生成物たるモノ及びヂメヂロール尿素とブチルアルュールとの部分的縮合物である事が解る。又同時にメチロ ール基は一部分メチレン基に攀化する。<smiles>CCCCNCCN</smiles>

a

$49.3_{0}^{0} \quad \mathrm{C}$

$19.2 \mathrm{~N}$

$9.6 \mathrm{H}$

21.90<smiles>CCOCNCOCNCCO</smiles>

$\mathrm{b}$

$47.7 \% \quad \mathrm{C}$

$15.9 \quad \mathrm{~N}$

$9.1 \quad \mathrm{H}$

$27.3 \quad \mathrm{O}$

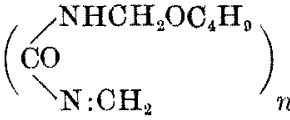

c

$53.2 \% \quad \mathrm{C}$

$17.7 \quad \mathrm{~N}$

$8.55 \mathrm{H}$

20.250

樹脂中に存在する其他の化合物としては（加熱前）次の漛なものが考へられる。<smiles>NCCNCCO</smiles>

d

$26.65 \% \quad \mathrm{O}$

$31.1 \quad \mathrm{~N}$

$6.65 \mathrm{H}$

$35.6 \quad 0$<smiles>C=NCCCCCCCCO</smiles>

$\mathrm{g}$

$35.3 \% \quad \mathrm{C}$

$27.5 \mathrm{~N}$

$5.9 \quad \mathrm{H}$

$31.4 \quad \mathrm{O}$

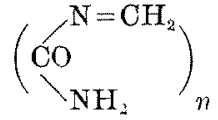

e

$33.3 \% \quad \mathrm{C}$

$38.9 \quad \mathrm{~N}$

$5.55 \quad \mathrm{H}$

$23.25 O$
$\overbrace{\mathrm{CHCH}_{2} \mathrm{OH}}^{\mathrm{NHCH}_{2} \mathrm{OH}}$

$\mathrm{NHCH}_{2} \mathrm{O}$

$30.0 \% \quad \mathrm{C}$

$233 \mathrm{~N}$

$6.7 \mathrm{H}$

$40.0 \quad 0$<smiles>C1=NC=NCCCCC1</smiles>

$\mathrm{h}$

$42.9 \% \quad \mathrm{C}$

$33.3 \mathrm{~N}$

$4.8 \mathrm{H}$

$19.0 \quad \mathrm{O}$

槿造式 $\mathrm{a}$ 或は $\mathrm{b}$ と $\mathrm{c}$ と混合物は第2表の結果に極めて近似してるる、若干の差の生ずるのは e、g 等が混 在してるるためと若へられる。之れに反し $\mathrm{d}$ 及 $\mathrm{h}$ は殆ど含有されて居らない事は明かである。

工業用フ*ルマリン中には若干（普通 5\%) のメチルアルコールを含有し、ために尿素 1 モル、フ*ルムア ルデヒド 3 モの混合液中にはフォルムアルデヒド1モルに付きメチルアルコールの $1 / 8$ モれを舍むことにな り、從つて之れがブチルアルコールと同樣に求素䨿にフォルムアルデとドと作用する事も考へられる。然し此 の樣な反應が行はれるとするとブチルアルコールのみが反應に與ると考へて行つた理諭構造式からの值と賽際 の分析結果との間に或程度差を生ずるのは當然の事である。

製 造

尿素ーフォルムアルデヒド一多價アルュールー多監基性酸の共同樎合物の製造 (31) は二段に行はれる。郎ちア ルキッド樹脂中間物の製造と次に之れと尿素ーフォルムアルデヒドとの縮合とである。

グリセロールーフタレート樹脂と尿素ーフォルムアルデヒド縮合物との結合物は淡色にして熱硬化性皮膜形成 村として賞用せられ且つ本報交の初めに記截したるが如き㱔造上並に眝藏上何らの困難がない。然しがリセ口 
ールーフタレートと尿素フフォムフルデヒドとの總べての組合せが此目的に䢛賞してるるのではなくして、其

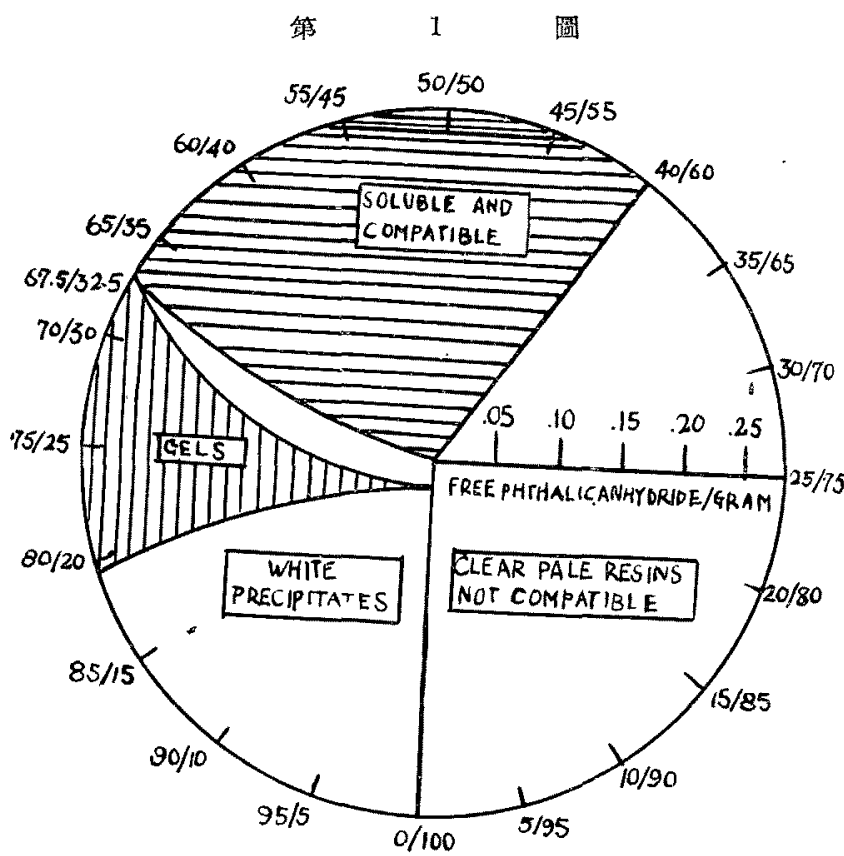

Figure 1. Soluble, Grl, and Precipitate areas of UreaFORMALDEHXDE MODIFIED RESINS

The first number represents the porcentage of urea-formaldehyde condensation product and the second the percentage of modifying asent; for oxampe, $0 / 100=0$ per cont urea-

散と共に樹脂は五に分離して皮膜吕゙白色化する。

尿素フフォルムアルデヒド樹脂の性質を改變せしめる目的でグリセリンーフタレート縮合物の種々の量を使用 して獨立せる數间の實驗を行つた場合には使用量の筙贵が大なる時は極めて不满足なる結果と成りその間に何 らの明劃なる關係が無い樣に思はれる事がある。然し乍ら詳細に多くの實驗を行ふ時は第】圖の如き圆面を劃 する事が出來る。次表は第 1 圖作成に探用したる實驗結果の一部分である。

\begin{tabular}{|c|c|c|c|c|c|}
\hline $\begin{array}{l}\text { 䨳 踰 } \\
\end{array}$ & $\begin{array}{l}\text { 尿素ーフォルん } \\
\text { アルデヒド\% }\end{array}$ & 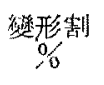 & 酸 低 & 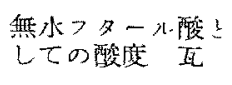 & 澍脂の狀態 \\
\hline 1 & 54 & 46 & - & - & 叮溶、相溶 \\
\hline 2 & 100 & 0 & $28 \mathrm{R}$ & - & 透时ゲル \\
\hline 3 & 100 & 0 & $49 \mathrm{R}$ & - & 白色沈澱 \\
\hline 4 & 58 & 42 & $165 \mathrm{M}$ & 0.218 & 可溶、相溶 \\
\hline 5 & 90 & 10 & $165 \mathrm{M}$ & 0.218 & 白色浓漂 \\
\hline 6 & 41 & 59 & $165 \mathrm{M}$ & 0.218 & 可溶、粗溶 \\
\hline 7 & 80 & 20 & $165 \mathrm{M}$ & 0.218 & 透明ゲル \\
\hline 8 & 40 & 60 & $36 \mathrm{M}$ & 0.048 & 遼明藳传 \\
\hline 9 & 0 & 100 & $72 \mathrm{M}$ & 0.095 & 透明、不相溶 \\
\hline 10 & 80 & 20 & $72 \mathrm{M}$ & 0.095 & 白色ら゙ル \\
\hline 11 & 70 & 30 & $198 \mathrm{M}$ & 0.264 & 白色ゲル \\
\hline 12 & 70 & 30 & $126 \mathrm{M}$ & 0.166 & 可溶、相溶 \\
\hline
\end{tabular}

籁園には一定限度がある。グリセロール ーフタレート 0 20\%、尿素ーフォルムアル デヒド 80〜100\%のの間ては非樹指狀の白

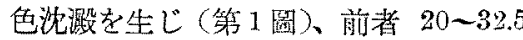
‥ 後者 67.5 80\% の場合には反應の 調節困踑で丞めで゙ル化し易い。然るに 前者 32.5〜60\%、後者 40〜67.5\%の間に 於て跦前記二種の場合と異り反隹進行は 涩足に調簛世られ、且つ共同縮合生成物 のブチルアルコール溶液は通常のアルキ ッド樹脂溶液及びミネラルスピリットの 如き安價なる溶劑にも良く混溶与る。更 に增加してグりセロールーフタレート 60 100\% 從つて尿素ーフォルムアルデヒ ド 0 40\%となるとブチルアルコール可 溶の湀色透明樹脂が得られるけれ共通常 のアルキット樹脂とは相溶しないものに なる。アルキット樹脂を溶液にすると混 溶するが、をれを塗裝する時は溶劑の揮 


$\begin{array}{llllll}13 & 74 & 26 & 126 \mathrm{M} & 0.166 & \text { 白色ゲル } \\ 14 & 40 & 60 & 165 \mathrm{M} & 0.218 & \text { 可溶、相溶 } \\ 15 & 25 & 75 & 165 \mathrm{M} & 0.218 & \text { 透明、不相溶 }\end{array}$

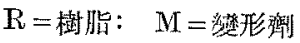

第 1 阔に示したる圖面の面積は次の特性を持つてるる。

\begin{tabular}{|c|c|}
\hline 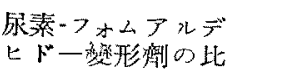 & 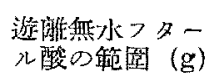 \\
\hline $0 / 100 \sim 25 / 75$ & $0 \sim 025$ \\
\hline $24 / 75 \sim 40 / 60$ & $0 \sim 0.25$ \\
\hline $40 / 60 \sim 67.5 / 32.5$ & $0 \sim 0.25$ \\
\hline $67.5 / 32.5 \sim 80.5 / 19.5$ & $0 \sim 0.25$ \\
\hline $80.5 / 195 \sim 100 / 0$ & $0 \sim 0.25$ \\
\hline
\end{tabular}

\section{面䅡 $の$ 種 類}

淡色透明樹脂、アルキッド薣脂と 不相溶。

透明、ゾル、アルキッド々相溶。 $25 / 75$ K近づくに從ひ不相溶。 透明、ゾル、アルキッド!相溶。

透明ゲル、但し境界線に沿ふては 白色及润攞のぶルを生ず。 白色沈晸、モノ一、攻びギメチロ 一兀化合物生成。

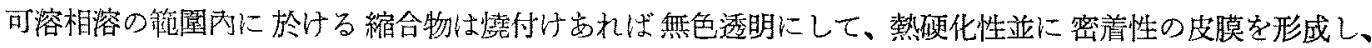

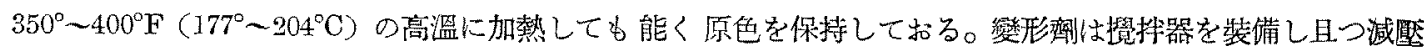
に酎ゆるステンレス・スチール製の密閉釜中にて製することが肝要である。

ダリ七ロールーフタレートは次の如くして作る、製水フタール酸 $3 モ ル （ 444$ 重量部）を化學用純グリセロ ール1モル (368 重量部) と共に $190^{\circ} \mathrm{C} に$ 加熱し、区應物の極少量を硝子板上に探りてその試料が透明とな るまで叉は酸價が 150〜170 に低下するまで熱する。原制の少量なる時は加熱時間は 15〜20 分で充分である が原料が多量なる場合には勿論特間は延長する。此の段階に達した時加熱を中止し冷却する。斯くして得られ る無色透明粘秱性の澍脂狀物を尿素ーファルムアルデヒド澍脂と結合やしめるのに用ひるのである。

第二段に於ける反應は既に述べたる如く此の變形劑の存在に於て尿素及びフォルムアルデヒドとの共同縮台

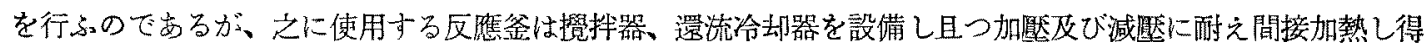
るものが良い。

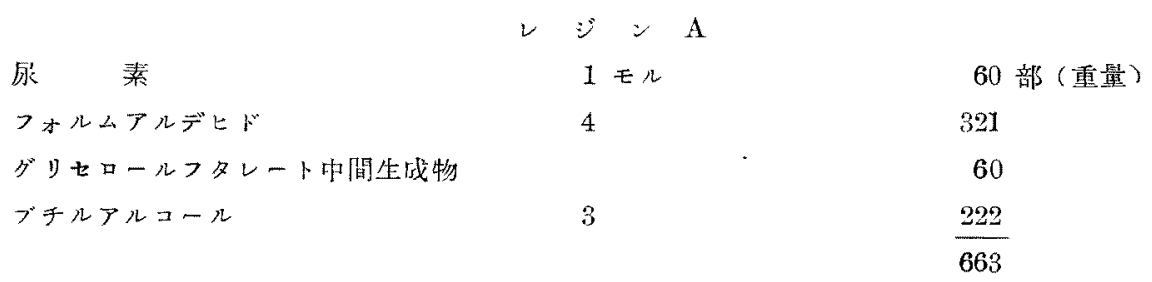

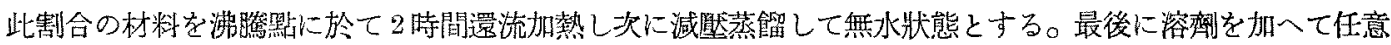
湴度 (莦通 50 ～60\%) の樹脂溶液とする。

共同縮合生成物の性質並に用途

從來世間では速乾性にして且つ强勒なる皮膜を形成する地らな樹脂を要求して居る。今日までは色合の濃い

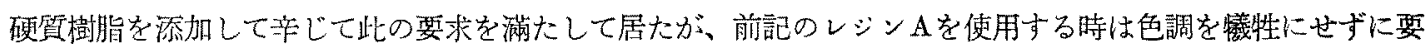
求性打を霂足せしめる事が出來るのである。

尿素ーフォルムアルデヒド樹脂は市販せられる樣になつてから既に久しいが、此樹脂は淡色で且つ色調保持の 
特徵を持つ反面に水分、濕氣に弱く接着力低く、變化し易く、又均一性及び相溶性に之しい。レジンAは此等 の䱃點を補つて居る許りでなく熱硬化性を有し䎶性樹脂殊にアルキッドの補强用として極めて有效である。此

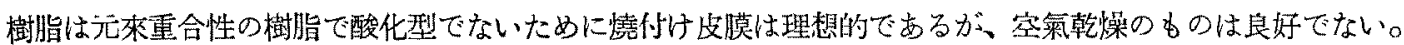

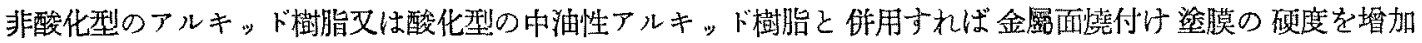
する。色調保持の點より言へばレジンAを非酸化型アルキッドに結合させたものが最も良好で酸化型アルキッ

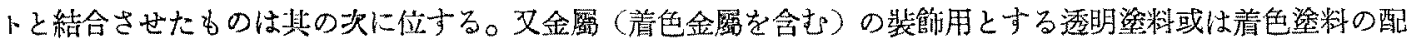
合に用ひて殊に有效で、唒且つ衝揧抵抗が大なるために金琶製家具、玩具、モーター、取技ひ激しい（殊に運 搬上）機械部分品に用ゆる整料として極めて好適である。

レジンAを正ーブチルアルコールに溶解やる $60 \%$ 液はコールタール系更び不油系の溶劑亚にェチルアルコ ール、ブチルアルコール、ェチルアセテート、ブチルア七テート及びェチレングリコール・エーテル等の溶 劑に完全に混合し、㕛酸化型及び非酸化型アルキ，ド並に硝化綿及びエチルセルローズ等にも良く混溶する。 レジンAは變色する棈な哥がないからエナメルを作るに際してもそのヴェとタルが顔料を活染する洯な事な く篇に多量の顏料を使用する必要がない。從つて特に光型を要求する如き場合には顏粦の使用量は少くて濟む

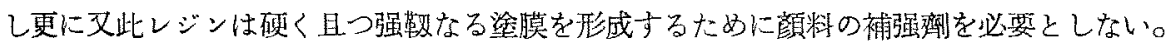

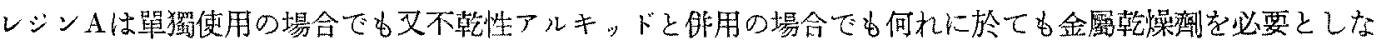
い。然し酸化型アルキッド樹脂と作用して低溫筑柇をする場合にのみ普通量の乾燥峢を添加する。

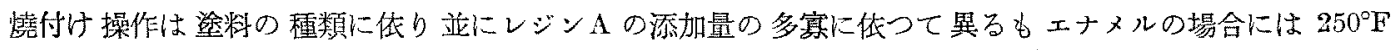
$\left(121^{\circ} \mathrm{C}\right)$ に 1 時間万至 $200^{\circ} \mathrm{F}\left(93^{\circ} \mathrm{C}\right)$ に 2 3 時間を普通とする。これより高溫なれば解水性、磶度及び耐

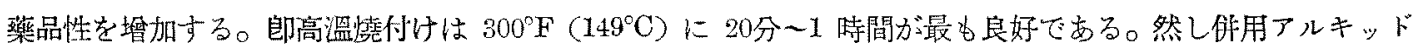
樹脂が非酸化型のものである䁌には $350^{\circ} \sim 400^{\circ} \mathrm{F}\left(177^{\circ} \sim 204^{\circ} \mathrm{C}\right)$ に於て焅付けても喓色化する樣な心配は絕體 にない。

第 2 圆

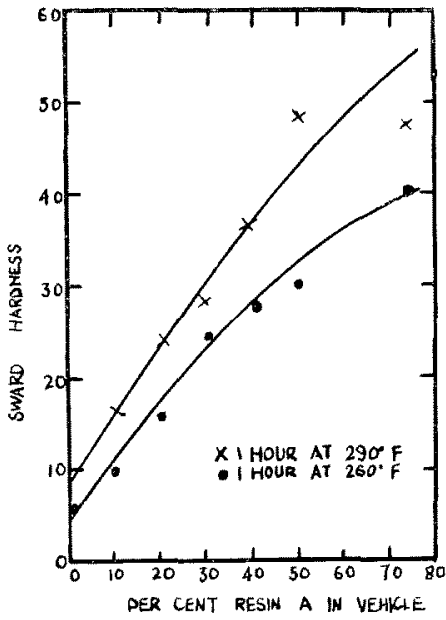

FIGURE 2. EEFECT OF ADDING Resin a to a Srort SemiOXIDIZING-TYPE ALKYD IN A White Pigmented ENAMEL Pigment/solid binder ratio $=1 / 0.8$
第 3 䍠

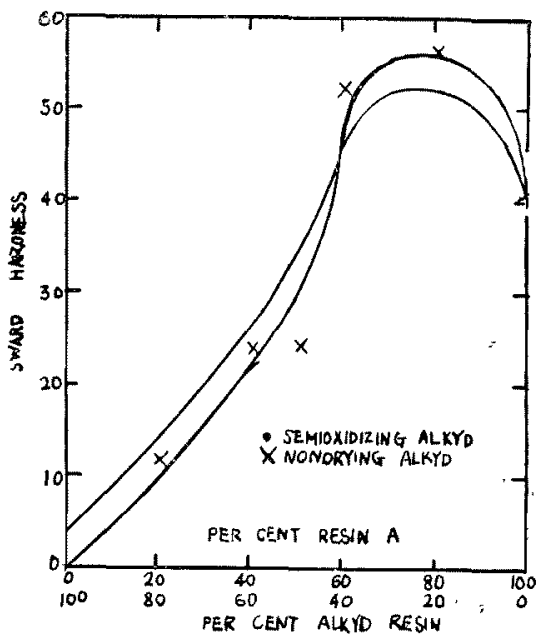

FiGURE 3. EEEECT OF Adding RESIN A

TO AN ALKYD

Baked 30 minntes at $300^{\circ} \mathrm{F}$. 
短本酸化型 short semioxidizing t.gpe)アルキッドを配合したエナメルにレジンAを添加したる場合の影響 は第 2 周に示した通りである。レジンA と短不乾性型アルキッドとの各㮔勧料よりは清澄透明の皮膜か汧成さ れる。(第 3 圆) 酸化型アルキッドを用ひた場合にも同樣なる關倸がある。

レジンAを比較的多量含有せる叙料を高溫にて筧付けた皮膜はアルコール、藥品及び溶劑に對して担抗力大 きく其の抵抗性は變形劑の性質に依るよりは寧ろ乾燥溫度に依つて左右せられるものである。それにしても抵 抗性大なる安定な變形劑が欲しいものである。

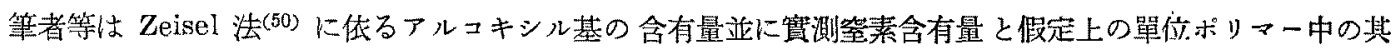

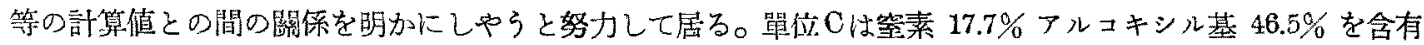

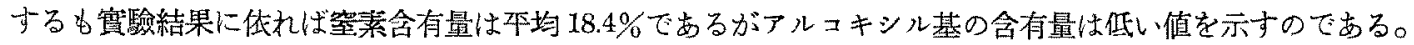
之れは化合物(50) 中の窒素の影響であらうと考へて居る。

結 論

1. 尿素とフォルムアルデヒドとの一般反應及び一值アルニールの存在にて行はれるアセタール反應及びー ミアセタール反應に就て論じ、殊に正ブチルアルコールの存在にて尿素ーフォルムアルデヒド反應により水不溶 皮膜歭成用縮合物を作る場合の正・ブチルフォルマールの作用效果について詳論した。

2. フォルムアルデヒドと多價アルュールとから椱就なるエーテルを形成する反隹並に此の反應と尿素フォ ルムアルデヒド樹脂及び多價アルコール一多監基性酸樹脂共同縮合反應との關係に就て檢討した。

3. ボリマー單位を次記の如きもの

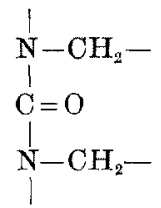

としての重合反應機構は最終坐成樹脂の物理的性質から考へて Redfarn 氏及び Ellis 氏等の構造說よりも合 理的である。

4. 一價及び多價アルコールの存在に於て縮合作用を行ふ侍中間物として生成するアセタールの構造及び物 理的性質を表示した。例へばフォルムアルデヒド1モルと正ブチルアルュール2モルとより正ブチルフォルマ ールが生成する。

$$
\mathrm{CH}_{2} \mathrm{O}+2 \mathrm{C}_{4} \mathrm{H}_{8} \mathrm{OH} \longrightarrow \mathrm{CH}_{2}\left(\mathrm{OC}_{4} \mathrm{H}_{9}\right)_{2}+\mathrm{H}_{2} \mathrm{O}
$$

アセタールの一般生成反應は

アセタール、

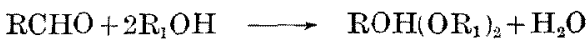

ヘミアセタール、

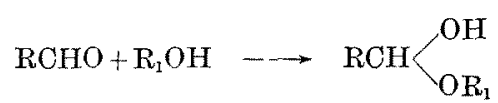

である。

5. 無水フタール酸1モルとエチレングりコール2モルとより得らる」複合多價アルコール(生成進行程度 は酸價測定に依りて調簛す)に閔する實騟結果並に其複合多價アルコールとフォルムアルデヒドとの反應結果 に就て論じた。 
6. 瓜素とアセタールとの一般反應は次の如く示される。

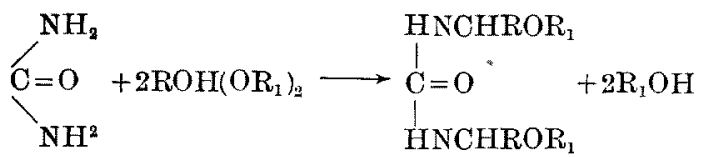

7. 尿素ーフォルムアルデヒド反應をブチルアルコールの存在で行はしめると其の中間樎合物は元素分析結果 から觀て多種物質の混合物である兼が解るが、然し大部分は次の化合物より成るもの」樣である。

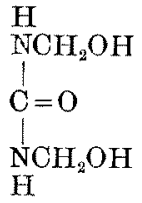

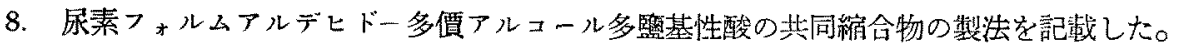

9. 尿素フォルムアルデヒドーアルキッドー共同縮合物の性質及び用途に就て述ペた。

10.アルキッド樹脂に尿素祖脂を添加した場合の影響（唀明皮膜及びエナメル皮膜に於て）を圆示した。

11. 逶明皮膜に於ては尿素 10\%、アルキッド樹脂 $90 \%$ の場合に硬度（Sward hardness）は 5 であるが前 者 $75 \%$ 、後者 $25 \%$ の時硬度は 50 に增大寸る。

\section{引用交献}

(1) Arnhold: Ann., 240, 199 (1887).

(2) Ibid., 240, 200 (1887).

(3) Beilstein, Handbuch der Organischen Chemie, Vol 1, pp. 575-6, 1918.

(4) Tbial, p. 603 .

(5) Ibid., pp. 603-4

(6) Ibid., p. 604 .

(7) Ibid., p. 605 .

(8) Ibid., Yol. 19, p. 2 (1934).

(9) Ibid, p. 11

(10) Ibid, p. 63

(11) Ibirl, p. 64.

(12) Ibid., p. 65.

(13) Ibid., p. 436

(14) Ibid., p. 439.

(15) Blaise: Compt. rend., 140, 662 (1905)

(16) Cheetham and Pearce: Puint, Oil Chrm. Rev., 99, 42, 44 (June 10, 1937); Official Dige $t$ Federation Paint \& Varnish Production Clubs, 8, No. 167, 216 20 (1936).

(17) Chesne, de: Kolloid-Beinefte, 36, 387 (1932).

(18) Crump: B. P. 309, 849 (1928).

(19) Delépine: Compt. rend., 131, 745 (19C0).

(20) Ibid., 131, 746 (1900)
(21) Dixon: .T. Chem. Soc., 113, 238 (1918),

(22) Du pont: Cempt. Renut., 148, 1523 (1909).

(23) Einborn and Hamberger: Ber, 41, 24 (1908).

(24) Ellis: "Chemistry of Synthetie Resins", Vol. 1, pp. 576 $\sim 87$

(25) Eilis: U. S. P. 2, 115,550 (April 26, 1938).

(26) Goldschmidt: Ber., 29, 24-38 (1896).

(27) Harnitziby and Menschutkin: Ann., 136, 127 (1865).

(28) Henry: Compt, rend., 120, 107, 1895.

(29) Hill and Walker; U. S. P. 1,877,13) (Sept. 13, 1932).

(30) Hölzer: Ber, 17, 659 (1884).

(31) Hovey and Hodgins: U. S. P. 2,109,291 (Feb. 22, 1938).

(32) John: Ibid., 1,355,834 (Oct. 19, 1920); B. P. 151,016 (1920).

(33) Lanter: U. S. P. 1,633,337 (June 21, 1927).

(34) Ludy: Monatsh, 10, 205, (1889); I. Chem. Soc., 56, 1059 (1889).

(35) Luther, Pungs, Griessback, and Henck;

U. S. P. 2019,865 (Nov. 5, 1935).

(36) Nef; Ann., 335, 215 (1904). 
(37) Toid., 335, 216 (1904).

(38) Ramstetter; D. R. P. 403,645(1922); J. Soc. Chem. Ind., 44, 216T (1925).

(39) Redfarn; Brit. Plastice, 5, 238 (1933).

(40) Richter: Organic Chemistry, 3rd ed, Vol. 1, p. 587.

(41) Ripper; U. S. P. 1,762,456 (June 10, 1930 ).

(42) Scheiber and Sändig. "Die Runstliehen Harze", p. 309.

(43) Scheibler, Trostler, and Schulz; Z. angent. chem., 41, 1305 (1928).

(44) Schulz and Tollens, Ann., 289, 27 (1896).
(45) Ibid., 289, 29(1896); Ber., 27, p. 1892-4 (1894).

(49) Staudinger; Ber, 59, 3019 (1926).

(47) Walter and Lutwak; Kolloid Beihefte, 40, $158(1934)$.

(48) Walter and Oesterreich; Ibit, 34, 115 (1981).

(49) Wurtrz; Compt. rend., 53, 378 (1861); Ann, 120, 328 (1845).

(50) Zeisel; 3rd Intern. Congr. Applied Chem, 2, 63 (1898); J. Chem. Suc., 81, 318, 115, 193 (1919) See also Kamm, "Qualitative Organic Analysis", 2nd ed., pp. 206-8. 